\title{
DEVELOPMENT OF A CASSAVA HARVESTER
}

\section{Isinkaye O.D., Koyenikan O.O. and Osadare T.}

The Federal Polytechnic, School of Engineering, Department of Agricultural and BioEnvironmental Engineering, PMB5351, Ado Ekiti, Ekiti State. Nigeria

Email ijeluekiti@gmail.com; Mobile +2347032614238

Cite this article:

Isinkaye O.D., Koyenikan O.O., Osadare T. (2021), Development of a Cassava Harvester. International Journal of Mechanical and Civil Engineering 4(1), 12-21. DOI: $10.52589 / \mathrm{IJMCE}-$ TWFGVKX1.

\section{Manuscript History}

Received: 20 Oct 2021

Accepted: 9 Nov 2021

Published: 27 Nov 2021

Copyright $\odot 2020$ The Author(s). This is an Open Access article distributed under the terms of Creative Commons AttributionNonCommercial-NoDerivatives 4.0 International (CC BY-NC-ND 4.0 ), which permits anyone to share, use, reproduce and redistribute in any medium, provided the original author and source are credited.
ABSTRACT: Cassava is a major source of food and raw material for domestic and industrial uses in Nigeria. Consequently, the technologies involved in its cultivation from planting to harvesting require proper development. This paper reports the development of a labour-saving technology for harvesting cassava using standard procedures for designing soil engaging implements. Locally available materials were also used in the fabrication of the harvester. Results of trial tests indicate a digging efficiency of 58.9\%, fuel consumption of $16 \mathrm{l} / \mathrm{ha}$, field capacity of $0.11 \mathrm{ha} / \mathrm{hr}$, field efficiency of $67.9 \%$ and root damage of $43.03 \%$. The total cost of fabricating the machine was 184,000 naira only. Further tests under various soil and operational conditions for improvement and optimization were recommended for the purpose of patenting for commercialization.

KEYWORDS: Cassava, Harvester, Fabrication, Digging, Efficiency, Roots. 


\section{INTRODUCTION}

Cassava is a basic food crop grown in several developing countries (Shackelford et al., 2018). Today, it is one of the world's most important food crops in tropical countries and ranks as the 6th most important food crop in the world.

Harvesting is the most challenging process in the production of cassava (Reinhardt Howeler et al., 2018). This is because cassava is a highly perishable crop and it starts to deteriorate after one to three days of harvest (Raju Saravanan et al., 2016). Therefore, harvesting cassava at the right time and in the right way is critical. Too early harvesting results in low yield and poor food quality; on the other hand, the central part becomes woody and inedible when the roots are left in the soil for too long (Amponsah, 2017). Cassava is ready for harvest as soon as storage roots are sufficiently large to satisfy the consumer's needs, from 6 to 7 months after planting, especially for most new cultivars of cassava. Mature roots cluster around the base of the plant and extend on all sides, approximately $60 \mathrm{~cm}$. The crop is grown for these roots which contain $15-40 \%$ starch. Under the most favourable conditions, fresh root yields can exceed 90t/ha, while average root yields are 10t/ha, mostly from subsistence farming systems. Traditionally, cassava is harvested by hand, raising the lower part of the stem and extracting the roots from the ground, and then removing them by hand from the base of the plant. Until harvesting, the top portions of the stems with the leaves are usually removed. It is possible to use levers and ropes to help harvest. It is also possible to use a mechanical harvester. Mechanical harvesters will grab the stem and raise the roots from the ground.

Developing labour-saving technologies for harvesting cassava has become the world's most important obstacle in the transformation of cassava (FAO \& IFAD 2005). Earlier attempts at mechanized harvesting were affected by constraints such as soil characteristics, tuber nature and size, cluster depth and width, and tuber bonding with soil, resulting in high tuber damage. Amponsah et al. (2010) state that, farm size and root tuber breakage level are critical factors considered in the selection and adoption of any method of harvesting cassava. Farmers around the globe have essentially three ways to harvest cassava: manual, semi-manual and mechanized.

Manual harvesting is the traditional method of harvesting cassava using bare hands with or without the use of native tools such as hoe, cutlass, mattock, earth chisel, etc. Manual harvesting takes about 22-62-man days per hectare (Nweke et al., 2011). The distinct unit operations for the harvesting of cassava include loosening the roots and pulling up the crops, removing the soil and separating the roots, collecting the roots and loading them for transport. Existing manual harvesting techniques contribute to drudgery and wasting, and they consume a lot of time as well as farm labour, which is scarce and expensive.

Additional benefits of using harvesters include a reduction in the total cost of production, an increase in labour productivity and a significant reduction in harvest losses and root damage. Several attempts have been made in developing cassava harvesters; it was discovered that those that were developed were with one defect or the other. This has necessitated the development of a new cassava harvester of better quality. 


\section{MATERIALS AND METHODS}

\section{Design Features}

The developed cassava harvester for harvesting cassava consists of the following components:

Frame: The frame is the skeletal structure that holds the whole parts of the implement together, and to which the point of attachment to the tractor three-point linkage is welded. The design factors considered in the determination of the material required for the frame are weight and strength.

Leg: The leg is the part of the cassava harvester that joins the frame to the shoe of the implement. The material selected for this part requires high strength and durability to withstand shock and vibrations during operation.

Shoe: This is the part of the cassava harvester that enters into the soil and lifts the cassava out of the soil; it has a sharp/pointed edge that enters into the soil.

Bolt and Nut: All the parts of the cassava harvester are coupled together by the means of bolt and nut at the respective joints.

Spikes: The spikes, which are welded to a flat bar, are attached to the shoe of the implement to shake off the soil from the cassava tuber as the implement lifts the cassava from the soil.

Point of Attachment (3-Point Linkage): The point of attachment is the point at which the implement is coupled/hitched to the tractor through the three-point linkages which are coupled with the procedure LEFT - RIGHT - TOP.

\section{DESIGN CALCULATIONS}

The design calculations were done using standard procedure reported by Godwin and Spoor (1978), Agbetoye et al. (2000) and Crossly (1983).

\section{Determination of Soil Force}

The average depth of the mature cassava tuber will help to determine the length of the digging shovel. Soil force required to uproot a mature cassava tuber is calculated using

$p=\gamma Z^{2} N \gamma+C Z N_{c a}+q Z N_{Q}$

where $\mathrm{Z}=$ working depth of digging shovel

$q=$ surcharge

$\gamma=$ bulk unit weight of the soil

$\mathrm{C}=$ cohesion

$N \gamma, N_{c a}, N_{Q}$ are dimensionless Reece factors

$\delta=$ angle of soil $/$ metal friction 


\section{Selection of Rake Angle}

The effective rake angle of complex shaped tines is the chord joining the working tip with the point where the line meets the soil surface.

$\alpha$

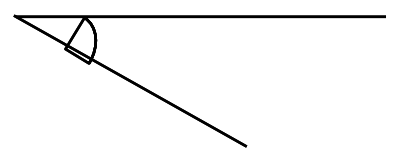

\section{Determination of Draft Per Unit Width (KN/m)}

Draft per unit width $(\mathrm{KN} / \mathrm{m})$ is obtained by using the equation:

$D=P \sin (\alpha+\delta)+C_{a} \operatorname{Cos} \alpha$

where $\quad \delta=$ angle of soil/metal frictions

$\alpha=$ rake angle

$C=\frac{C_{\propto} Z}{\operatorname{Sin} \propto_{a}} \quad(\mathrm{Z}=$ working depth of digging shovel $)$

\section{Determination of Vertical Force Per Unit Width (KN/m)}

This was obtained using the formula below:

$V=P \cos (\alpha+\delta)+C_{a} \operatorname{Sin} \alpha$

\section{Determination of Power Requirement Per Unit Width}

This was obtained using the formula below:

$P_{o}=\mathrm{D} \cdot \mathrm{V}$

where $\mathrm{D}=$ draft force in $\mathrm{KN} / \mathrm{m}$

$\mathrm{V}=$ tractor forward speed $(\mathrm{m} / \mathrm{s})$

\section{Determination of Tensile Stress of the Bolt}

Tensile stress of the bolt is obtained using the equation:

$\mathrm{P}=\frac{\pi d c^{2}}{4} \times \delta t($ Crossley, 1983)

where $d_{c}=$ diameter of the thread

$\delta_{t}=$ permissible tensile stress for bolt materials 


\section{Determination of Shear Stress}

Shear stress of the bolt is obtained using the equation (Crossley, 1983) given as:

$\gamma_{s}=\frac{\pi d^{2}}{4} \times \tau$

where $\mathrm{d}=$ major diameter of the bolt, $\tau=$ number of bolts

\section{Determination of Weight of Digging Material}

Volume of soil with digger $=A \times H$

where $\mathrm{A}=$ cross sectional area of digger

$$
\begin{aligned}
& \mathrm{H}=\text { Height } \text { of soil level on digger } \\
& \mathrm{M}=\rho_{\text {soil }} \times V_{\text {soil }}
\end{aligned}
$$

Weight of the digger $(\mathrm{w})=\mathrm{m} \times \mathrm{g}$

$$
g=9.81
$$

\section{Determination of Rupture Distance Ratio}

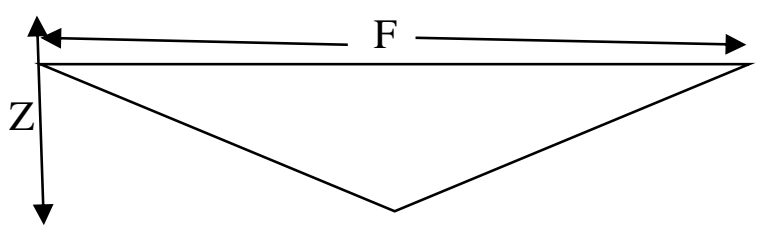

This is obtained using the formula below:

$\mathrm{M}=\frac{F}{Z}$ 


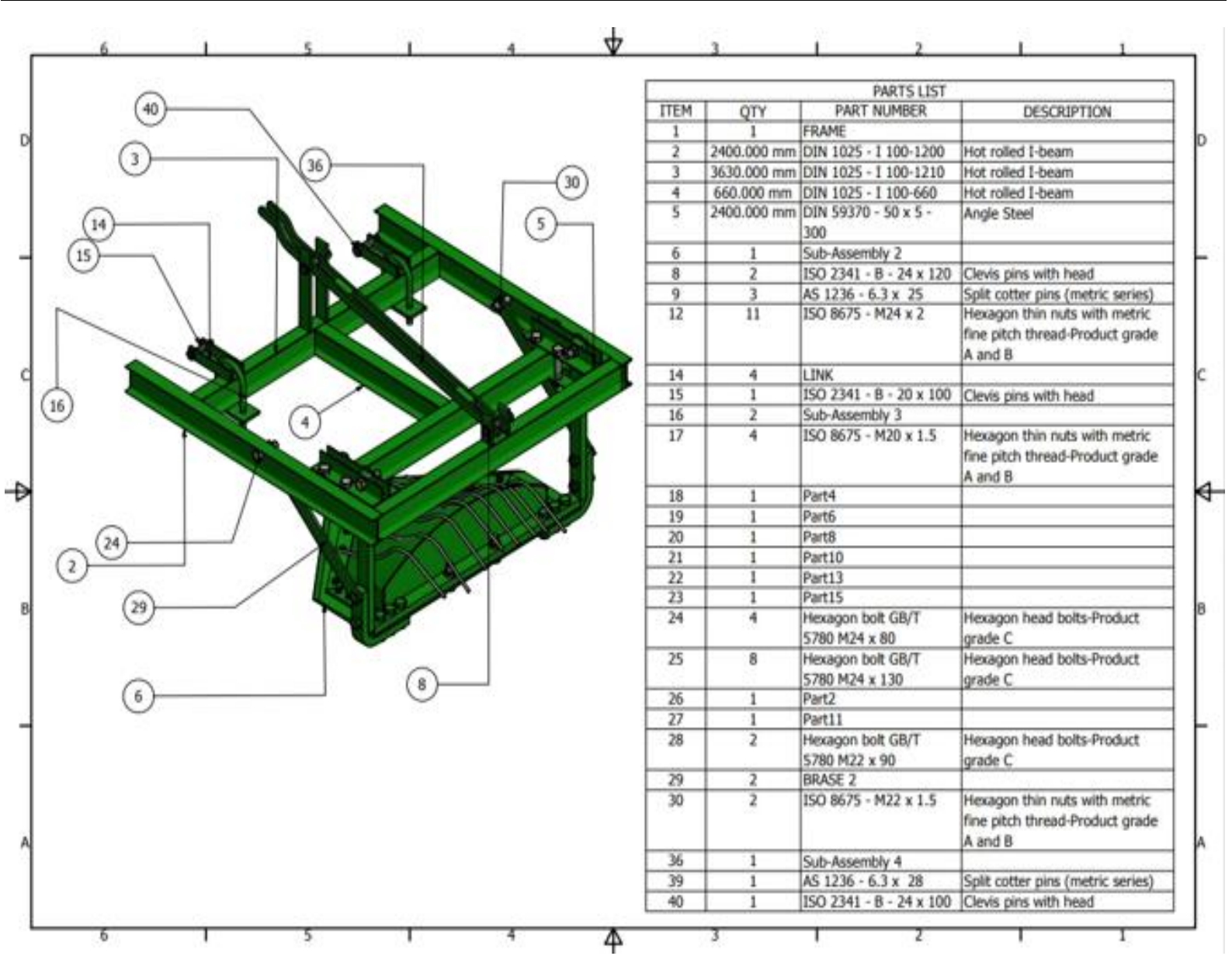

Figure 1: Fabricated cassava harvester showing component parts

\section{Fabrication of the Machine}

Fabrication of the cassava harvester involves cutting, bending, grinding, joining and drilling of metals of various sizes and shapes as shown in Figure 1.

\section{Testing of the Cassava Harvester}

Trial tests were conducted to examine the effectiveness of the implement in harvesting cassava compared to that of the digging shovel; the ability to penetrate into the soil and dig up cassava tuber without considerable damage is an important factor in evaluating its performance.

A well mechanized farm was used for the harvesting operation. The implement was coupled to the tractor appropriately through the three-point linkage, starting from the left link to the right link and to the top link, and was conveyed to the farm. The cassava stem of each row was cut and cleared to ease the operation of the implement, then the tractor mounted with implement was positioned at the start of the first row. The implement was lowered into the soil and was driven through the row at a required speed to the top end of the row. The implement was raised up at the top end and a U-turn movement was made to position the implement at the tip end of the other row. The implement was lowered once again and then driven through the row to harvest the cassava. 
International Journal of Mechanical and Civil Engineering

ISSN: $2689-940 \mathrm{X}$

Volume 4, Issue 1, 2021 (pp. 12-21)

www.abjournals.org

\section{RESULTS AND DISCUSSION}

\section{Results}

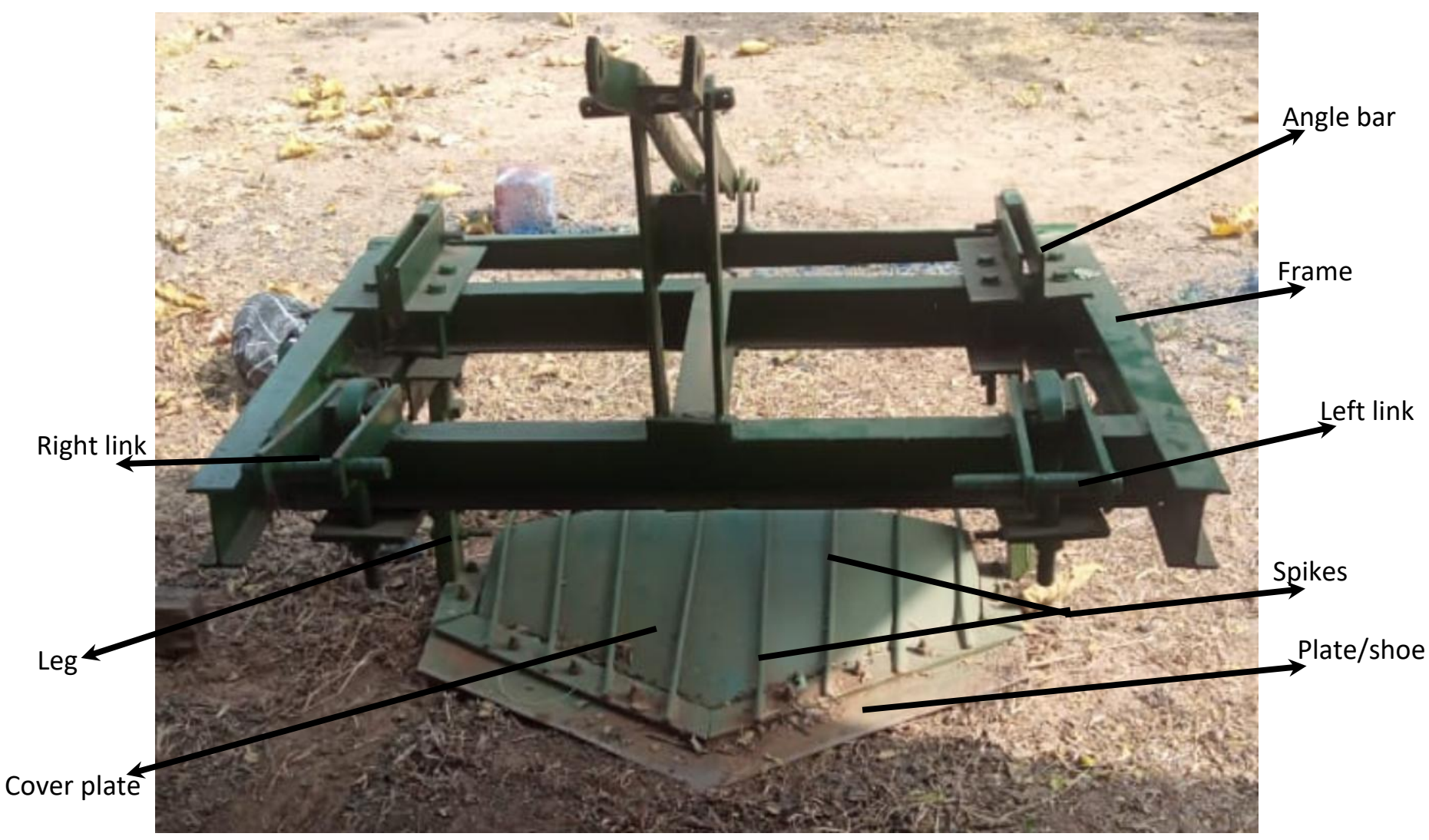

Plate 1: Fabricated Cassava Harvester

\section{Test Results of the Machine}

The results obtained from the field test of the cassava harvester were used to determine the following parameters:

\section{Digging Efficiency}

After the harvesting of the cassava tubers, dug tubers were weighed. The area was then inspected for undogged tubers which were manually dug out from the soil. The undugged tubers were also weighed.

Dug tubers $=24.10 \mathrm{~kg}$, total root yield $=40.9 \mathrm{~kg}$

Digging Efficiency $=\frac{\text { dug tubers }}{\text { total root yield }} \times 100 \%=\frac{24.10}{40.9} \times 100 \%=58.9 \%$ 
The digging efficiency obtained is lower when compared with that of other cassava harvesters, which may be partly due to the fact that the testing was conducted during the dry season and the field was not prepared specifically for the testing.

\section{Theoretical Field Capacity}

$\mathrm{TFC}=\frac{\operatorname{width}(\mathrm{cm}) \times \operatorname{speed}\left(\frac{m}{s}\right) \times 36}{10000}$

Width $=200 \mathrm{~cm}$, speed of harvesting operation $=0.225 \mathrm{~m} / \mathrm{s}$

$$
\mathrm{TFC}=\frac{200 \times 0.225 \times 36}{10000}=0.162 \mathrm{ha} / \mathrm{hr}
$$

\section{Effective Field Capacity (C)}

Area covered $=20 \times 1.6 \times 1=32 \mathrm{~m}^{2}$

Time of operation $=105 \mathrm{sec}=0.029 \mathrm{hr}$

$\mathrm{C}=\frac{A \times 3600}{10000 \times t}(\mathrm{ha} / \mathrm{hr})=\frac{32 \times 3600}{10000 \times 105}=0.11 \mathrm{ha} / \mathrm{hr}$

The field capacity obtained is higher than that of the cassava digger produced by Thangdee and Wongpichet (2012) which was $0.05 \mathrm{ha} / \mathrm{hr}$, and higher than that of the tractor operated cassava digger produced by Jesudas et al. (2014) which was $0.07 \mathrm{ha} / \mathrm{hr}$.

\section{Field Efficiency}

Field efficiency $=\frac{\text { effective field capacity }}{\text { theoretical field capacity }} \times 100 \%=\frac{0.11}{0.162} \times 100=67.9 \%$

Field efficiency is higher than that of the cassava digger produced by Thangdee and Wongpichet (2012) which was 59.10\%.

\section{Depth of Penetration}

The sample depth penetration test results are shown in Table 1.

Table 1: Lists of different depth penetration samples

\begin{tabular}{lc}
\hline No of Samples & Depth of Penetration (cm) \\
\hline 1 & 17 \\
2 & 18 \\
3 & 11 \\
4 & 9 \\
5 & 14 \\
Average depth of penetration & 13.8 \\
\hline
\end{tabular}

Average depth of percentage $=\frac{17+18+11+9+14}{5}=13.8 \mathrm{~cm}$ 


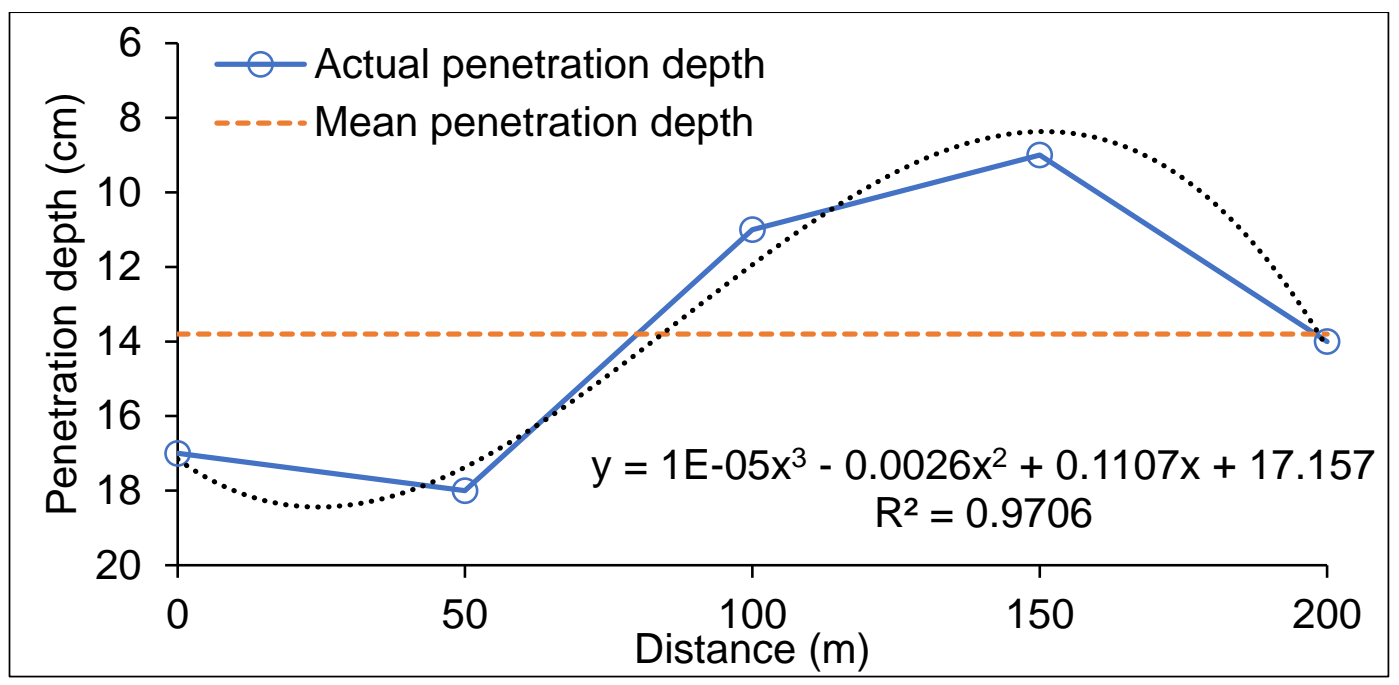

Figure 2: Machine penetration depth against horizontal

The average depth of penetration obtained was much lower than the one obtained from TEK mechanical harvester which was $20.7 \mathrm{~cm}$. This was also due to the moisture content of the soil and the soil condition; this test was carried out during the dry season when moisture content of the soil was very low.

\section{Root Tuber Damage Assessment}

The percentage root tuber damage was calculated using:

Percentage damage $=\frac{\text { mass of damaged roots }(\mathrm{kg})}{\text { total root yield }(\mathrm{kg})} \times 100$

Total root yield $=40.9 \mathrm{~kg}$, mass of damaged roots $=17.6 \mathrm{~kg}$

$$
=\frac{17.6}{40.9} \times 100=43.03 \%
$$

The percentage of root damage is much higher than that of other harvesters due to the fact that the test was carried out during the dry season and the field was not prepared for the use of the harvester.

\section{CONCLUSION AND RECOMMENDATIONS}

\section{Conclusion}

A Cassava harvester was designed and fabricated in the Department of Agricultural and BioEnvironmental Engineering, Federal Polytechnic, Ado-Ekiti.

Locally sourced materials were used in the fabrication, which consist of digging shoe to dig the cassava, conical board to shake off attached soils, frame, legs and three-point linkage. 
Test results showed that digging efficiency was $58.9 \%$, fuel consumption was $16 l / h a$, field capacity $0.11 \mathrm{ha} / \mathrm{h}$, average depth of penetration was $13.8 \mathrm{~cm}$, field efficiency was $67.9 \%$ and percentage damage of the roots was $43.03 \%$.

\section{Recommendations}

1. The implement gives more percentage of damage due to dry season and the high compaction of the soil. Therefore, it is more recommended to be used during the wet season when the soil is moistened reasonably well for efficient results.

2. Further tests under various soil and operational conditions for improvement and optimization should be carried out for the purpose of patenting for commercialization.

\section{REFERENCES}

Agbetoye, L. A. S., Dyson, J. and Kilgour, J. (2000): Prediction of the Lifting Forces for Cassava Harvesting. Jornal. agric. Engineering Research. 75: 39-48.

Amponsah, S.K, Addo A. and Gangadharan (2017). Review of various harvesting options for Cassava. IntechOpen.com

Amponsah, S.K, Sheriff, J.T. and Byju, G. (2010): Comparative evaluation of manual cassava harvesting techniques in Kerala India. Agric. Eng. Int. CTCRI.; pp.16:41-52.

FAO and IFAD (2005): Proceeding of the validation form on the Global Cassava Development Strategy, Volume 2. A review of cassava in Africa with country case studies on Nigeria, Ghana, the United Republic of Tanzania, Uganda and Benin.

Godwin RJ Spoor G. (1978). An experimental investigation into the deep loosening of soil by rigid tines. Journal of Agricultural Engineering Res., 23 (3) (1978) pp. 243-258.

Hall, A.S., Holowenko, A.R., Laughing H.G (1982): Machine design. Mc Grawhill, Singapore $3^{\text {rd }}$ edition pp. 45 .

National Center for Agricultural Mechanization NCAM, (2013): Review of Various Harvesting Options for Cassava. http://dx.doi.org/10.5772/intechopen.71350 Review of Various Harvesting Options for Cassava http://dx.doi.org/10.5772/intechopen.71350 pp: 303.

Nweke, F.I.; Dixon, A.G.O.; Asiedu, A. and Folayan, S.A. (2011): Cassava varietal needs of farmers and the potential for production growth in Africa. Pp: 32, 89-90.

Raju Saravanan, Vinisa Ravi, R. Stephen, S. Tajuddin \& J. George (2016): Post-harvest physiological deterioration of cassava - A review. Researchgate.net

Reinhaerdt Howeler, Peter Cain, Larry Trumbore and Sapto Utomo Hidajat (2018): The Challenge of large-Scale cassava production. Researchgate.net 